\title{
Disease control strategies for extending storage life of papaya (Carica papaya), cultivars 'Red Lady' and 'Rathna'
}

\author{
K. Abeywickrama ${ }^{1}$, C. Wijerathna ${ }^{1}$, N. Rajapaksha ${ }^{1}$, K. Sarananda ${ }^{2}$ and S. Kannangara ${ }^{1}$ \\ ${ }^{\mathbf{1}}$ Department of Botany, Faculty of Science, University of Kelaniya, Kelaniya, Sri Lanka. \\ ${ }^{2}$ Food Research Unit, Gannoruwa, Peradeniya, Sri Lanka.
} Accepted 02 April 2012

\begin{abstract}
Anthracnose (Colletotrichum gloeosporioides), stem-end rot (Lasiodiplodia theobromae) and Phomopsis rot (Phomopsis caricae-papayae) are major post-harvest diseases in papaya resulting in relatively high postharvest losses, up to $45 \%$, in Sri Lanka. The current consumer preference is for tropical fruits free of synthetic pesticides. The objectives of the present investigation were to identify major post-harvest pathogens in papaya fruits, test in vitro fungitoxic effect of basil oil (Ocimum basillicum) and alum (sodium aluminium sulphate) on major fungal pathogens of papaya fruit and develop a relatively safe, disease control strategy. Alum $(1 \% \mathrm{w} / \mathrm{v})$ and basil oil $(0.12-0.16 \% \mathrm{v} / \mathrm{v})$ in a liquid bioassay, indicated fungistatic and fungicidal efficacy on $C$. gloeosporioides, L. theobromae and P. caricae-papayae isolated from 'Red Lady' and 'Rathna' cultivars of papaya. In vivo investigation of fruits of both papaya cultivars harvested from fruit plantations in Sri Lanka ('Red Lady'-Yatawarawatta plantation, Kurunegala, 'Rathna' - CIC plantation, Kekirawa and the Agricultural farm, Polonnaruwa) at 25\% maturity level indicated that papaya washed in $1 \%(\mathrm{w} / \mathrm{v})$ alum and subsequently sprayed with an emulsion solution of $0.16 \%(\mathrm{v} / \mathrm{v})$ basil oil and enclosed in styrofoam sleeves could be stored for 14 days at $12-14{ }^{\circ} \mathrm{C}$. The visual quality rating (VQR) was high (11-13), shriveling and 'green islands' were low on fruits with zero disease severity where results were statistically similar to $500 \mathrm{mg} / \mathrm{L}$ Bavistin treatment. Physicochemical properties assessed were unaffected by the treatments and were comparable to the controls washed only in water. The organoleptic properties were slightly low in fruits subjected to cold temperature compared to fruits subjected to ambient temperature. No residues of basil oil could be detected on fruit peel by gas chromatography at the end of the experimental period of 14 days. The treatment strategy developed could be adopted for sea shipment or temperature-regulated supermarket storage of papaya fruits where storage life could be lengthened up to 14 days.
\end{abstract}

Key words: Ocimum basillicum, anthracnose, stem-end rot, fungicidal, cold storage

\section{INTRODUCTION}

Papaya (Carica papaya L.) is a delicious and nutritive fruit which has a high demand in the local and international markets. It is cultivated in Sri Lanka primarily as a home garden crop. Kurunegala district is the highest producer of papaya in the country. Kaluthara, Rathnapura, Gampaha, Galle, Anuradhapura, Puttalam, Hambantota and Badulla are the other districts that have large extents of papaya cultivations (Rajapakse and Gunadasa, 2002). However, mechanical damages caused during harvesting, transport and post-harvest diseases result in considerable post-harvest loss of papaya fruits. Post-harvest losses of papaya in Sri Lanka are reported to be about $45 \%$ (Sarananda et al., 2004). Mechanical damage caused at pre and postharvest stages and post-harvest diseases are the major causes for postharvest loss in papaya fruits. Papaya fruits after harvest are affected by surface rots (Rhizopus sp.), stem end rot (Lasiodiplodia theobromae), and internal mould due to Phomopsis caricae-papayae (Coates et al., 1995; Mitra, 1997). Anthracnose disease in papaya is caused by the latent pathogen Colletotrichum gloeosporioides. Slightly lesser taste of fruits and very high incidence of 'Green Islands' (areas of skin that remain green and sunken) have reduced the consumer demand for this commodity. The formation of 'Green Islands' when the fruit is fully ripe is apparently induced by mechanical injury (Quintana and Paull, 1993).

Packaging and cushioning material help to reduce vibration damage to fruits during transport. A previous research conducted in Sri Lanka resulted in identifying the importance of harvesting 'Rathna' papaya fruits at 25-50\% yellow stage and packing individual fruits in styrofoam sleeves (cushioning material) for managing post-harvest diseases to a certain

*Corresponding author's email: kris@kln.ac.lk 
extent (Sarananda et al., 2004).

Chemical treatments are suitable for fruits which have a relatively longer post-harvest life and for preventing primary infections. However, treating a short-life commodity with a fungicide that has a long residual activity cannot be justified. The success of chemical treatments also depends on several factors such as, initial spore load, the growth rate of the infection, temperature, humidity and the depth to which chemicals sprayed can penetrate to inside tissues (Ploetz et al., 1994).

Alum (sodium aluminium sulphate, $1 \% \mathrm{w} / \mathrm{v}$ ) is used in Sri Lanka and in certain other countries to wash fruits such as papaya, banana and mango to prevent latex dripping (Wijerathnam, 2002). Latex deposition could stain fruits as well as have an adverse effect on the visual appeal and quality of fruits. However, fungicidal property of alum has not been tested.

After harvesting papaya fruits, spray treatment with essential oils can be used instead of systemic fungicides, to extend the storage life and to control diseases. It is important to maintain the post-harvest quality of papaya for export via sea/air freight and for continuous supply to the local market. Various essential oils such as Indian sweet basil (Ocimum basilicum) and West Indian Lemongrass (Cymbopogon citrates) have been tested in vitro and in vivo for their antifungal efficacy on post-harvest pathogens of banana and mango (Anthony et al., 2003).

The objectives of this investigation were to identify in vitro fungicidal efficacy of basil oil and alum treatment on 'Rathna' and 'Red Lady' cultivars of papaya and to develop a treatment strategy utilizing basil oil plus alum, appropriate temperature and cushioning material for disease control, green island suppression and storage life lengthening of papaya for local consumption and export. We have made an attempt to test the hypotheses that (1) post-harvest diseases of papaya fruits are low when treated with alum plus basil oil (in combination with low temperature and cushioning) and (2) Green Island incidence is less when treated as above.

\section{MATERIALS AND METHODS}

\section{Chemicals}

Ocimum basilicum oil and Bavistin FL (500 g/L carbendazim) were purchased from Aromatica Laboratories Pvt. Ltd, Colombo 11, Sri Lanka (import agents of basil oil) and BASF-Finlay (Pvt.) Ltd., Colombo 2, Sri Lanka respectively. Alum (sodium aluminium sulphate) was purchased from Rathee Chemicals, Colombo, Sri Lanka.

\section{Isolation and purification of post-harvest fungal pathogens}

'Red Lady' and 'Rathna' papaya fruits were collected from home gardens and markets in Alawwa, Gampaha, Ja-ela, Pita-kotte, Kelaniya, Kiribathgoda, Kadawatha, Kurunegala, Kumbukwewa, Kandy, Nawala, Nugegoda and Nittambuwa. Papaya fruits with post-harvest diseases/symptoms were placed in a moist chamber for about 24 hours to induce the production of conidia of pathogens. A circular glass tank (30 cm in diameter and $25 \mathrm{~cm}$ depth) with a glass lid was used as a moist chamber. The bottom of the glass tank was lined with tissue paper and moistened with sterile distilled water.

After incubation, diseased papaya fruit tissues $\left(1 \mathrm{~cm}^{2}\right)$ were cut under aseptic conditions. The tissues were surface sterilized by soaking the sections in freshly prepared Clorox solution $(3 \% \mathrm{w} / \mathrm{v})$ for 5 minutes. After three serial washings in sterile distilled water, papaya tissues $\left(5 \mathrm{~mm}^{2}\right)$ were placed (2 pieces per plate) on Potato Dextrose Agar (PDA) plates and incubated at room temperature $\left(28 \pm 2{ }^{0} \mathrm{C}\right)$ in the laboratory of the Department of Botany, University of Kelaniya. Isolated and identity confirmed post-harvest fungal pathogens of papaya were grown in pure culture on Potato Dextrose Agar (PDA) for 7 days (Anthony et al., 2004).

\section{Effect of basil oil and alum on the growth of post-harvest fungal pathogens of papaya in liquid bioassay}

A concentration series $(0.04,0.08,0.12$ and 0.16 $\%$ v/v) of Ocimum basilicum oil, $1 \%$ w/v alum were prepared and added using a micropipette to separate sets of $100 \mathrm{ml}$ conical flasks containing a sterilized and cooled semi-synthetic liquid medium/SMKY (20 g Sucrose, $0.5 \mathrm{~g} \mathrm{MgSO}_{4}, 3 \mathrm{~g}$ $\mathrm{KNO}_{3}, 7 \mathrm{~g}$ Yeast extract in $1000 \mathrm{ml}$ of distilled water) as six replicates per treatment (Anthony et al., 2004; Barata et al., 1998). A drop of Tween-80 (Koch's Light) was added as a surfactant to oil containing flasks to dispense oil evenly. Sterile SMKY medium without any treatment served as the negative control and Bavistin (500 mg/L) served as the positive control (Anthony et al., 2004; Barata et al., 1998). All flasks were inoculated with a $5 \mathrm{~mm}$ diameter mycelia disc from a 7 day old pure culture. Contents were mixed thoroughly by placing the flasks on a reciprocal water bath shaker (Model G2, New Brunswick, USA) for 
$10 \mathrm{~min}$ and all flasks were arranged on a laboratory bench as a Completely Randomized Design (CRD) and incubated for 7 days at ambient temperature $\left(28 \pm 2{ }^{0} \mathrm{C}\right)$. Minimum Inhibitory Concentration (MIC, i.e. the lowest oil concentration, which suppressed the growth of each test pathogen indicating fungistatic activity) was noted. Where the growth was completely inhibited by test oil, fungal discs were transferred to fresh PDA plates without any treatment and after 7-day incubation, Minimum Lethal Concentration (MLC) of basil oil against test pathogens was noted (i.e. fungicidal effect). The lethal effect of $1 \%(\mathrm{w} / \mathrm{v})$ alum was also noted (Barata et al., 1998, Anthony et al., 2004).

\section{In vivo treatment of papaya var. 'Red Lady'}

Papaya cultivar 'Red Lady' at 25\% yellow stage, with no records of pre- or post-harvest fungicidal treatment, were harvested from Yatawarawatta plantation, Kurunegala, Sri Lanka and individually enclosed in styrofoam net sleeves, packed stem-end-down in ventilated plastic crates and transported to the laboratory. Fruits were divided into sets of 16 fruits and weights of fruits were recorded using an electronic balance (Sartorious BP 6100, R \& M marketing, UK). Except for one set of fruits, all other fruits were washed in water and then in $1 \%$ alum solution. The remaining set was washed using water only. Fruits were allowed to air dry for half an hour and was subjected to a set of treatments such as basil oil spray $(0.16 \% \mathrm{v} / \mathrm{v})$ or Bavistin $(500$ $\mathrm{mg} / \mathrm{L}$ ) until fruits were completely soaked (12$15 \mathrm{ml}$ ) ( Rajapaksha, 2006; Sarananda et al., 2004). Treated and control papaya fruits were individually enclosed in styrofoam net sleeves and placed stem end down in ventilated plastic crates $\left(63 \times 43 \times 30 \mathrm{~cm}^{3}\right)$ as a single layer $(8$ fruits per crate and 2 replicate crates per treatment). One batch of treated fruits and control were incubated at $12-14{ }^{0} \mathrm{C}$ and $85-90 \%$ relative humidity in a Walk-in cold room for 14 days and placed in an air conditioned room $\left(25 \pm 2{ }^{\circ} \mathrm{C}\right)$ for 2-3 days until naturally ripened (Experiment 1). A similar batch of fruits was subjected to the same experimental conditions and temperatures without enclosing papaya in styrofoam sleeves (Experiment 2) (Sarananda et al., 2004). The group of treatments enclosed in stryrofoam sleeves was subjected to ambient temperature $\left(28 \pm 2{ }^{\circ} \mathrm{C}\right)$ (Experiment 3$)$. Experiment 1, 2 and 3 was repeated once.

\section{In vivo treatment of papaya var. 'Rathna'}

Papaya cultivar 'Rathna' at $25 \%$ yellow stage, with no records of pre- or post-harvest fungicidal treatment, were harvested from CIC plantation,
Kekirawa (North Central Province) and Agricultural Farm, Department of Agriculture, Polonnaruwa, Sri Lanka. Papaya fruits were divided into sets of 16 fruits and treated (as in experiments 1, 2, and 3), packed and incubated as in 'Red Lady' var. papaya. All experimental conditions were identical to the conditions described above for 'Red Lady' cultivar papaya. 'Rathna' papaya treated and enclosed in styrofoam sleeves and subjected cold temperature was designated as experiment 4 whereas the group of fruits without Styrofoam padding served as Experiment 5. Papaya fruits stored at ambient temperature with styrofoam padding served as Experiment 6 (Rajapaksha and Gunadasa, 2002; Sarananda et al., 2004). Experiment 4, 5 and 6 were repeated once.

After natural ripening, fruits from each treatment, were analyzed for the physicochemical, organoleptic and pathological properties. Firmness was measured using a portable Fruit firmness tester (Model d-6336 Friedbery, Germany), where as TSS was recorded using a hand-held refractometer (Atago, Japan). Peel colour was assessed using harvest maturity indices developed at the Department of Botany, University of Kelaniya and Food Research Unit, Gannoruwa.

Visual quality ratings (11-13=high quality, 6$10=$ good quality, 4-5=bad quality, 1-3=very bad quality) were assigned considering the criteria, 'green island' formation, shriveling and disease severity of papaya. The severity of 'Green Island' formation was recorded using a 1-5 index developed by Quintana and Paull (1993) (1=none, $2=$ few number of incidence, $3=$ moderate incidence, $4=$ high number of incidence, 5=very high number of incidence). The degree of shriveling of papaya fruits were recorded using a 1-4 index developed by Quintana and Paull, (1993) (1= no shriveling, 2=slight shriveling, $3=$ moderate shriveling, $4=$ severe shriveling). Disease severity due to surface rots, anthracnose, stem-end rot, internal rot due to fungi naturally occurring in papaya in treatments and control were assessed using indices developed by Quintana and Paull, (1993) and Sarananda et al. (2004) (1=slightly diseased, $2=$ moderately diseased,3=high disease, 4=very high disease).

An untrained taste panel of 10 members was used to obtain a feed back on sensory properties of papaya fruits subjected to treatments/controls. Each quality parameter was scored according to Sarananda et al. (2004) (90-100\%=Excellent, $60-80 \%=$ Good, $40-50 \%=$ Fair, $10-30 \%=$ Poor $)$. 
Extraction of essential oil components from papaya peel and residue analysis

Papaya cultivar 'Red Lady' at $25 \%$ maturity (3 fruits per treatment) were washed with $0.16 \%$ $\mathrm{v} / \mathrm{v}$ basil oil and stored in a cold room at 12-14 ${ }^{0} \mathrm{C}$ and $85-90 \%$ RH for 14 days. Subsequently, individual fruits were weighed using an electronic balance and peeled with a sharp knife. Peels of three fruits were combined and subjected to hydro distillation using a Nicholson-Nickelson apparatus. Any oil present in the peel was trapped in n-Pentane (Cox et al., 1974). The extract collected was subjected to Gas Liquid Chromatographic analysis at Industrial Technology Institute, Colombo, Sri Lanka. A Shimadzu 14B GLC equipped with a Supelcowax TM capillary column and a flame ionization detector was used. The GLC conditions used were; carrier gas $\operatorname{Ar} 1.8 \mathrm{ml} / \mathrm{min}$, temperature $60{ }^{\circ} \mathrm{C}$ for $0.5 \mathrm{~min}$ and then heated to $225{ }^{0} \mathrm{C}$ at $5{ }^{0} \mathrm{C} / \mathrm{min}$ and kept for $10 \mathrm{~min}$. The detector temperature was $230{ }^{0} \mathrm{C}$ and injector port temperature was $240{ }^{0} \mathrm{C}$ (Paranagama, 1991). An attempt was made to identify the constituents of basil oil in peel by comparing with relative retention times of an authentic sample of sweet basil.

\section{RESULTS AND DISCUSSION}

'Red Lady' and 'Rathna' are two major cultivars of papaya which have been identified by the Department of Agriculture for successful cultivation in Sri Lanka. 'Red Lady' is redfleshed cultivar introduced to Sri Lanka from Taiwan whereas 'Rathna' is the only cultivar that has been released by the Department of Agriculture in Sri Lanka (Sarananda et al., 2004, www.agridept.gov.lk).

\section{Isolation and purification of post-harvest fungal pathogens of papaya}

Three post-harvest fungal pathogens (Colletotrichum gloeosprioides, Lasiodiplodia theobromae and Phomopsis carica-papayae) and Rhizopus stolonifer were isolated and identified from diseased specimens of 'Red lady' and 'Rathna' papaya fruits. Identity of the pure cultures were confirmed by comparing morphological features of specimens with published keys (Abeywickrama, 2006) and the fungal collection maintained at the Department of Botany, University of Kelaniya. Morphological characters of pathogens identified are in agreement with characters previously described by (Coates et al., 1995 and Mitra, 1997).
Effect of $\boldsymbol{O}$. basilicum oil (basil oil) and alum $(1 \% \mathrm{w} / \mathrm{v})$ on the growth of post-harvest fungal pathogens of papaya in liquid bioassay Ocimum basilicum oil was effective in demonstrating fungistatic (MIC) and fungicidal (MLC) effects against post-harvest pathogens, $C$. gloeosporioides, L. theobromae and P. caricaepapayae at a narrow concentration range of $0.04-0.08 \% \quad(\mathrm{v} / \mathrm{v})$ and $0.12-0.16 \% \quad(\mathrm{v} / \mathrm{v})$ respectively. No growth of $P$. caricae-papayae was observed in the liquid medium in the presence of $0.16 \%(\mathrm{v} / \mathrm{v})$ basil oil. There was no mycelial growth of pathogens in $1 \%$ alum and bavistin treatments whereas a luxuriant growth and conidia formation of papaya pathogens was observed in the control. The data obtained and observations of the in vitro study suggest that $0.16 \%(\mathrm{v} / \mathrm{v})$ basil oil and (1\% w/v) alum can be used as an alternative to fungicidal treatments to control the post-harvest pathogens of papaya. The observations with respect to basil oil are in agreement with data published by Anthony et al. (2004) and Abeywickrama et al., 2009 against banana fruit pathogens. A previous research conducted by Herath and Abeywickrama (2008), resulted in the identification of leakage of cell contents of conidia of C. musae and Fusarium proliferatum (isolated from banana) after treatment with basil oil using Spectrophotometry. With increasing concentration of the oil, higher level of leakage could be observed compared with the control indicating marked membrane activity against conidia of both pathogens (Herath and Abeywickrama, 2008). This indicates the possible mechanism of action of basil oil (which contains eugenol and many other volatile components) on fruit fungal pathogens.

Effect of in vivo treatments on papaya var. 'Red Lady' and 'Rathna'

Severity of Phomopsis rot, anthracnose and stem-end rot of papaya fruits was visually assessed. Untreated control fruits of papaya cultivar 'Red Lady' of the three experiments 1, 2 and 3 were infected with surface rots, stem-end rot and anthracnose by the end of storage period. All fruits of 'Rathna' and 'Red Lady' papaya subjected to cold temperature were free of postharvest diseases when treated with alum or alum + basil oil in comparison to the control. Shriveling was slightly low (1-1.5) in treated fruits of both varieties compared to the controls (Tables 1 and 2).

'Green islands' formation was less in alum + basil oil treated 'Red Lady' and 'Rathna' samples compared to the control in all six experiments (Tables 3 and 4). In both papaya 
cultivars, the highest visual quality rating was shown by the alum + basil oil treated papaya $(\mathrm{VQR}=11-13)$ and results were statistically similar to the bavistin treatment. Ratings were given by considering 3 criteria, namely, green islands formation, shriveling and disease severity of papaya (Sarananda et al., 2004). Before transportation to the laboratory, fruits of both cultivars were enclosed in styrofoam sleeves and carefully packed stem-end down in ventilated plastic crates as a single layer to minimize mechanical damage. According to Balasuriya (2001), spongy nature of styrofoam padding helps to absorb the mechanical forces and reduce the vibration damage during transport causing lesser skin damage which may have contributed to some extent to the low number of 'Green islands' and better visual quality of fruits.

Table 1. Disease severity and shriveling of papaya var. 'Red Lady' treated with $1 \%$ alum wash, $1 \%$ alum wash + basil oil or bavistin.

\begin{tabular}{lcccccc}
\hline & \multicolumn{3}{c}{ Disease severity } & \multicolumn{3}{c}{ Shriveling $^{\mathbf{y}}$} \\
\cline { 2 - 7 } & Exp.1 & Exp. 2 & Exp.3 & Exp. 1 & Exp. 2 & Exp. 3 \\
\hline Alum & $0^{\mathrm{a} 1,2}$ & $0^{\mathrm{a}}$ & $0.50^{\mathrm{a}}$ & $1^{\mathrm{c} 1,2}$ & $1^{\mathrm{c}}$ & $1.5^{\mathrm{c}}$ \\
Alum + 0.16\% basil oil & $0^{\mathrm{a}}$ & $0^{\mathrm{a}}$ & $0.30^{\mathrm{a}}$ & $1^{\mathrm{c}}$ & $1^{\mathrm{c}}$ & $1.4^{\mathrm{c}}$ \\
Control & $2^{\mathrm{b}}$ & $1.5^{\mathrm{b}}$ & $3^{\mathrm{b}}$ & $2^{\mathrm{d}}$ & $2^{\mathrm{d}}$ & $1.5^{\mathrm{c}}$ \\
Bavistin & $0^{\mathrm{a}}$ & $0^{\mathrm{a}}$ & $0^{\mathrm{a}}$ & $1^{\mathrm{c}}$ & $1^{\mathrm{c}}$ & $1.5^{\mathrm{c}}$ \\
\hline
\end{tabular}

${ }^{\mathrm{T}}$ Each data point represents the mean of 32 replicates.

${ }^{2}$ Means followed by a common letter are not significantly different by Kruskal Wallis non-parametric statistical test (P $>0.05)$.

${ }^{\mathrm{x}}$ Disease severity: 1 = slightly diseased, $2=$ moderately diseased, $3=$ high disease and $4=$ very high disease; ${ }^{\text {y }}$ Shriveling: $1=$ no shriveling, $2=$ slight shriveling, $3=$ moderate shriveling and $4=$ severe shriveling.

*Exp 1=Enclosed in styroform sleeves and stored at cold temperature $\left(12-14^{\circ} \mathrm{C}\right)$, Exp $2=$ Stored at cold temperature $\left(12-14^{0} \mathrm{C}\right)$ without enclosing in styroform sleeves, Exp $3=$ Enclosed in styroform sleeves and stored at ambient temperature $\left(28 \pm 2^{0} \mathrm{C}\right)$.

Table 2. Disease severity and shriveling of papaya var. 'Rathna' treated with $1 \%$ alum wash, $1 \%$ alum wash + basil oil and bavistin.

\begin{tabular}{|c|c|c|c|c|c|c|}
\hline \multirow[b]{2}{*}{ Treatment } & \multicolumn{3}{|c|}{ Disease severity index ${ }^{x}$} & \multicolumn{3}{|c|}{ Shriveling index ${ }^{y}$} \\
\hline & Exp. 4 & Exp. 5 & Exp. 6 & Exp. 4 & Exp. 5 & Exp. 6 \\
\hline Alum & $0^{\mathrm{a}, 1,2}$ & $0^{\mathrm{a}}$ & $0^{\mathrm{a}}$ & $1^{\mathrm{c}}$ & $1^{\mathrm{c}}$ & $1.5^{\mathrm{d}}$ \\
\hline Alum $+0.16 \%$ basil oil & $0^{\mathrm{a}}$ & $0^{\mathrm{a}}$ & $0^{\mathrm{a}}$ & $1^{\mathrm{c}}$ & $1^{\mathrm{c}}$ & $1.5^{\mathrm{d}}$ \\
\hline Control & $1^{\mathrm{a}}$ & $1^{\mathrm{a}}$ & $2^{b}$ & $2^{\mathrm{d}}$ & $2^{\mathrm{d}}$ & $2^{\mathrm{d}}$ \\
\hline Bavistin & $0^{\mathrm{a}}$ & $0^{\mathrm{a}}$ & $0^{\mathrm{a}}$ & $1^{\mathrm{c}}$ & $2^{\mathrm{d}}$ & $1^{\mathrm{c}}$ \\
\hline
\end{tabular}

${ }^{1}$ Each data point represents the mean of 32 replicates.

${ }^{2}$ Means followed by a common letter are not significantly different by Kruskal Wallis non-parametric statistical test (P $>0.05)$.

${ }^{\mathrm{x}}$ Disease severity: 1 = slightly diseased, 2 = moderately diseased, $3=$ high disease and 4 = very high disease;

${ }^{y}$ Shriveling: $1=$ no shriveling, $2=$ slight shriveling, $3=$ moderate shriveling and $4=$ severe shriveling.

$* \operatorname{Exp} 4=$ Enclosed in styroform sleeves and stored at cold temperature $\left(12-14^{\circ} \mathrm{C}\right)$, Exp $5=$ Stored at cold temperature $\left(12-14^{0} \mathrm{C}\right)$ without enclosing in styroform sleeves, Exp $6=$ Enclosed in styroform sleeves and stored at ambient temperature $\left(28 \pm 2^{0} \mathrm{C}\right)$. 
Table 3. Green island formation and visual quality rating of papaya var. 'Red Lady' treated with $1 \%$ alum wash, $1 \%$ alum wash + basil oil and bavistin.

\begin{tabular}{lcccccc}
\hline & \multicolumn{3}{c}{ Green island formation } & \multicolumn{2}{c}{ Visual quality rating $^{\mathbf{y}}$} \\
\cline { 2 - 7 } & Exp.1 & Exp.2 & Exp.3 & Exp.1 & Exp.2 & Exp.3 \\
\hline Alum & $1^{\mathrm{a}, 2}$ & $1^{\mathrm{a}}$ & $1^{\mathrm{a}}$ & $11^{\mathrm{c} 1,2}$ & $11^{\mathrm{c}}$ & $9^{\mathrm{d}}$ \\
Alum $+0.16 \%$ basil oil & $1^{\mathrm{a}}$ & $1 \mathrm{a}$ & $1.3^{\mathrm{a}}$ & $12^{\mathrm{c}}$ & $11^{\mathrm{c}}$ & $11^{\mathrm{c}}$ \\
Control & $2^{\mathrm{b}}$ & $2^{\mathrm{b}}$ & $3.3^{\mathrm{b}}$ & $8^{\mathrm{d}}$ & $9^{\mathrm{d}}$ & $8^{\mathrm{d}}$ \\
Bavistin & $2^{\mathrm{b}}$ & $2^{\mathrm{b}}$ & $2.2^{\mathrm{b}}$ & $13^{\mathrm{c}}$ & $12^{\mathrm{c}}$ & $12^{\mathrm{c}}$ \\
\hline
\end{tabular}

${ }^{1}$ Each data point represents the mean of 32 replicates.

${ }^{2}$ Means followed by a letter are not significantly different by Kruskal Wallis non-parametric statistical test $(\mathrm{P}>0.05)$.

${ }^{\mathrm{z}} \mathrm{VQR}$ index: 11-13=high quality, 6-10=good quality, 4-5=bad quality and 1-3=very bad quality; ${ }^{\mathrm{y}}$ Green islands: $1=$ none, $2=$ few number of incidence, $3=$ moderate incidence, $4=$ high number of incidence and $5=$ very high number of incidence

* Exp 1=Enclosed in styroform sleeves and stored at cold temperature $\left(12-14^{0} \mathrm{C}\right)$, Exp $2=$ Stored at cold temperature $\left(12-14^{0} \mathrm{C}\right)$ without enclosing in styroform sleeves, Exp $3=$ Enclosed in styroform sleeves and stored at ambient temperature $\left(28 \pm 2^{0} \mathrm{C}\right)$.

Table 4. Green island formation and visual quality rating of papaya var. 'Rathna' treated with $1 \%$ alum wash, $1 \%$ alum wash + basil oil and bavistin.

\begin{tabular}{|c|c|c|c|c|c|c|}
\hline \multirow[b]{2}{*}{ Treatment } & \multicolumn{3}{|c|}{ Green island formation ${ }^{y}$} & \multicolumn{3}{|c|}{ Visual quality rating $^{z}$} \\
\hline & Exp. 4 & Exp. 5 & Exp. 6 & Exp. 4 & Exp. 5 & Exp. 6 \\
\hline Alum & $1^{\mathrm{a} 1,2}$ & $2^{b}$ & $1^{\mathrm{a}}$ & $10^{\mathrm{c}}$ & $11^{\mathrm{c}}$ & $11^{\mathrm{c}}$ \\
\hline Alum $+0.16 \%$ basil oil & $1^{\mathrm{a}}$ & $1^{\mathrm{a}}$ & $1.5^{\mathrm{a}}$ & $12^{\mathrm{c}}$ & $12^{\mathrm{c}}$ & $11^{\mathrm{c}}$ \\
\hline Control & $2^{b}$ & $2^{b}$ & $2^{\mathrm{b}}$ & $9.5^{\mathrm{d}}$ & $8^{\mathrm{d}}$ & $9^{d}$ \\
\hline Bavistin & $1^{\mathrm{a}}$ & $2^{\mathrm{b}}$ & $1^{\mathrm{a}}$ & $12^{\mathrm{c}}$ & $12^{\mathrm{c}}$ & $12.5^{\mathrm{c}}$ \\
\hline
\end{tabular}

${ }^{\mathrm{T}}$ Each data point represents the mean of 32 replicates.

${ }^{2}$ Means followed by a common letter are not significantly different by Kruskal Wallis non-parametric statistical test (P $>0.05)$.

${ }^{\mathrm{z}} \mathrm{VQR}$ index: 11-13=high quality, 6-10=good quality, $4-5=$ bad quality and 1-3=very bad quality; ${ }^{\mathrm{y}}$ Green islands: $1=$ none, $2=$ few number of incidence, $3=$ moderate incidence, $4=$ high number of incidence and $5=$ very high number of incidence

* Exp 4=Enclosed in styroform sleeves and stored at cold temperature $\left(12-14^{0} \mathrm{C}\right)$, Exp $5=$ Stored at cold temperature $\left(12-14^{0} \mathrm{C}\right)$ without enclosing in styroform sleeves, Exp $6=$ Enclosed in styroform sleeves and stored at ambient temperature $\left(28 \pm 2^{0} \mathrm{C}\right)$.

At the end of the experimental period of 14 days at cold storage, the peel colour of both papaya fruits of all treatments remained at $25 \%$ yellow colour stage (i.e. more green than yellow $=3$ ). After natural ripening, peel attained the highest and preferable peel colour of full yellow within 2-3 days. This observation is supported by previous research data published on 'Rathna' papaya (Sarananda et al., 2004). The fruit firmness and TSS of all fruit samples of 'Red Lady' and 'Rathna' were similar and were not significantly different to the control. Percentage weight loss was slightly less $(<5.1 \%)$ in 'Red Lady' than in 'Rathna' $(<5.8 \%)$. The latter result could be due to storage at a relatively higher room temperature of $28 \pm 2{ }^{\circ} \mathrm{C}$.

According to our observations, alum + basil oil treated 'Red Lady' papaya indicated higher/better organoleptic properties (48-63\%) compared to other treatments. Moreover, organoleptic properties were better in fruits subjected to ambient temperature in all treatments and control in Experiment 3 which ranged between $58-82 \%$. The same was true for 
'Rathna' stored at ambient temperature (Experiment 6). An increase in odour, taste and flavour were seen $(67-80 \%)$ in all fruits irrespective of the treatment in experiment 6 . This indicates the importance of storage at a relatively high temperature for most preferred flavour, taste and odour development in papaya fruits.

\section{Analysis of papaya peel for residues of basil oil}

Methyl chavicol, eugenol and linalool, which were present in the authentic basil oil sample, were absent in the gas chromatogram obtained from 'Red Lady' papaya peel extract after the storage period. We assume that the fruits are free from oil residues due to the volatile nature of basil oil. Chromatogram however, displayed many other peaks which correspond to volatile substances given off during fruit ripening. A similar trial conducted by Anthony (2003), reported the absence basil oil on Embul banana peel (based on gas chromatography) after a period of 21 days at $13.5^{\circ} \mathrm{C}$ storage.

In conclusion, the treatment strategy developed could be adopted for sea shipment of papaya fruits and temperature regulatedsupermarket storage up to 14 days.

\section{ACKNOWLEDGEMENTS}

The authors thank the International Foundation for Science (IFS), Sweden and National Science Foundation (NSF), Sri Lanka for funding this research investigation. Authors acknowledge the assistance provided by Mr. Ranjith Dayananda during gas chromatography analysis and the technical staff at Food Research Unit, Gannoruwa and Department of Botany, University of Kelaniya, Sri Lanka.

\section{REFERENCES}

Abeywickrama, K. (2006). A pictorial guide to rapid and accurate identification of postharvest diseases of fruits. Godage International Publishers (Pvt) Ltd., Colombo, Sri Lanka.

Abeywickrama, K., Wijerathna, C., Herath, H. and Sarananda, K.H. (2009). An integrated treatment of basil oil (Ocimum basilicum) and alum with modified atmosphere to control crown rot disease in Embul banana. Tropical Agricultural Research \& Extension 12(1):23-30.
Anthony, C.L.S. (2003). Essential oil treatments to control two post-harvest diseases in fruits of banana (Musa acuminata - cultivar Embul). M.Phil Dissertation submitted to Faculty of Graduate Studies, University of Kelaniya.

Anthony, S., Abeywickrama, K., Dayananda, R., Wijerathnam, S.W. and Arabewela, L. (2003). The effect of spraying essential oils of Cymbopogon nardus, C. flexuosus and Ocimum basilicum on post-harvest diseases and storage life of Embul banana. Journal of Horticultural Science and Biotechnology 78(6): 780-785.

Anthony, S., Abeywickrama, K., Dayananda, R., Wijeratnam, S.W. and Arabewela, L. (2004). Fungal pathogens associated with banana fruit in Sri Lanka and their treatment with essential oils. Mycopathologia 157(1): 91-97.

Balasuriya, S. T. (2001). Postharvest longevity of papaya (Carica papaya L.) as affected by methods of handling. M.Sc Dissertation, University of Peradeniya, Sri Lanka.

Barata, M.T., Dorman, H.J.D., Deans, S.S.G., Figueredo, A.C., Barroso, J.G. and Ruberto, G. (1998). Antimicrobial and antioxidant properties of some commercial antimicrobial essential oil. Flavour and Fragrence Journal 13: 235-244.

Coates, L., Cooke, T., Persley, D., Beattie, B., Wade, N. and Ridgway, R. (1995). Tropical Fruit: Post-harvest Diseases of horticultural produce. Vol 2, State of Queensland Department of Primary Industries, Australia.

Cox, J., Donegan, L. and Pinegar, J.A. (1974). The estimation of surface residues of benomyl on treated banana. Pesticide Science 5: 135-145.

Department of Agriculture, Government of Sri Lanka (2006). Crop Recommendations papaya. http://www.agridept.gov.lk/index. php/en/crop-recommendations/1101 $(15 / 02 / 2006)$

Herath, $\mathrm{H}$ and Abeywickrama, Krishanthi (2008). In vitro application of selected essential oils and their major components in controlling fungal pathogens of crown rot in Embul banana (Musa acuminata - AAB). International Journal of Food Science and Technology 43: 440-447.

Mitra, S. (1997). Postharvest physiology and storage of tropical fruits .CAB International, UK.

Paranagama, P. (1991). Analysis of Sri Lankan essential oils by Gas Chromatography and Mass Spectroscopy. Industrial Technology Institute, Colombo, Sri Lanka.

Ploetz, R.C., Zentmyer, G.A. and Nishijima, 
W.T. (1994). Compendium of Tropical Fruit Disease. American Phytopathological Society, USA. Pp. 2-22.

Quintana, M.E.G. and Paull, R.E. (1993). Mechanical injury during Postharvest handling of 'Solo' papaya fruit. Journal of American Society for Horticultural Science 118(5): 618-622.

Rajapaksha, L.M. and Gunadasa, H. (2002). Market Information Report 2.0: Fruit. National Agribusiness Council, Colombo, Sri Lanka.

Rajapaksha, R.P.N.V. (2006). Effect of basil oil (Ocimum basilicum) emulsion spray and Alum in controlling postharvest fungal pathogens of papaya (Carica papaya L.) cultivars "Red Lady" and "Rathna". B.Sc. Dissertation. Department of Botany, University of Kelaniya, Sri Lanka.

Sarananda, K.H., Balasuriya, S.T. and Ganeshalingam, K. (2004). Quality of papaya variety 'Rathna' as affected by post-harvest handling. Tropical Agriculture Research and Extension 7: 72-78.

Wijerathnam, S. W. (2002). The Postharvest Management of Banana. Global Conference on Banana and Plantain, October 20-31, 2002, Bangalore, India, Pp. 42-46. 